\title{
FRUIT QUALITY INDICATORS OF APPLE (MALUS DOMESTICA BORKH.) CULTIVARS BRED IN UKRAINE
}

\author{
Liudmyla SHEVCHUK*, Igor GRYNYK, Liudmyla LEVCHUK, \\ Svitlana BABENKO, Hryhorii PODPRIATOV, Petro KONDRATENKOD \\ Institute of Horticulture of National Academy of Agrarian Sciences of Ukraine, Ukraine \\ Received: August 2021; Accepted: November 2021
}

\begin{abstract}
As a result of the evaluation of the physical and biochemical quality indicators of the fruit of thirteen apple cultivars of Ukrainian breeding, it was found that the fruits of 'Teremok', 'Skifs'ke Zoloto', 'Amulet', 'Perlyna Kyieva', 'Harant', 'Edera', 'Radohost', 'Todes' and 'Askol'da' are characterized by high stability of market traits based on the maximum diameter of the equatorial dimension, which varies depending on the cultivar, from $70 \mathrm{~mm}$ to $78 \mathrm{~mm}$. The firmness of the fruit flesh of the evaluated cultivars in the harvest maturity was over $7.0 \mathrm{~kg} \cdot \mathrm{cm}^{-2}$ but in 'Solomiya' and 'Dmiana' this indicator was $11.1 \mathrm{~kg} \cdot \mathrm{cm}^{-2}$. The fruits of 'Harant' and 'Todes' were distinguished by a high dry matter content (over 18\%). The highest content of soluble solids $(14.5 \%)$ was accumulated in the fruits of 'Dmiana', and the maximum amount of sugars (11.6\%) in the fruit of the 'Ornament'. The fruits of 'Teremok', 'Skifs'ke Zoloto', 'Amulet', 'Edera', 'Perlyna Kyieva', 'Kateryna' and 'Dmiana' were characterized by excellent taste quality based on the values of the sugar-acid index (20-25). In the fruits of 'Kateryna', 'Dmiana' and 'Solomiya', a stable pectin content (over 1\%) was found. The fruits of 'Harant' accumulated a high content of ascorbic acid $\left(11.5 \mathrm{mg} \cdot 100 \mathrm{~g}^{-1}\right.$ of fresh weight), while 'Kateryna', 'Radohost', 'Solomiya' and 'Askol'da' contained over $240 \mathrm{mg} \cdot 100 \mathrm{~g}$ '1 of fresh weight of polyphenols. According to the complex of the quality indices, the fruits of 'Teremok', 'Skifs'ke Zoloto', 'Perlyna Kyieva', 'Askol'da' and 'Dmiana' were distinguished by high commercial value and excellent consumption properties. The fruits of 'Kateryna', 'Ornament', 'Dmiana' and 'Solomiya' were characterized by stable carbohydrate content, while 'Harant' and 'Askol'da' by a stable high content of ascorbic acid and polyphenols, respectively.
\end{abstract}

Key words: ascorbic acid, dry mass, flesh firmness; fruit size, pectins, polyphenols, sugars

\section{INTRODUCTION}

Apples are one of the most popular and frequently consumed fruits in the regions of temperate climate, where their production rises year after year. Good appearance, crunchy flesh, pleasant taste and aroma result from morphological, physiological and biochemical characteristics of fruit, which are determined largely by the genotype, agricultural practices, weather conditions of the year as well as the degree of ripeness (Ali et al. 2004; Nour et al. 2010; Ciesa et al. 2013; Skordas et al. 2013). It is known that the chemical diversity (aroma and taste), as well as sensory and nutritional qualities are higher in older apple cultivars compared to modern ones (Ciesa et al. 2015; Donno et al. 2012). Oszmiański et al. (2018) reported that in 22 old apple cultivars the content of polyphenols ranged from 1348.40 to $4310.52 \mathrm{mg}$ per $100 \mathrm{~g}$ of dry weight, sugars from 7.41 to $11.99 \mathrm{~g}$ per $100 \mathrm{~g}$ of fresh weight, pectins from 0.64 to $2.24 \mathrm{~g}$ per $100 \mathrm{~g}$ of fresh weight. In studies of Panzella et al. (2013), Faramarzi et al. (2015) and Feliciano et al. (2010), all older apple cultivars from southern Italy, Iran, and Portugal showed higher polyphenol content than commercial apple cultivars. 
Thus, the biochemical composition of the fruits must be assessed not less meticulously than physical quality indices, such as mass, size, color and firmness (Amiri et al. 2014). Besides, apples are the most important source of polyphenolic compounds in European countries, thanks to their wide availability throughout the year (Wolfe et al. 2003). The pro-health properties of apple fruits are also enhanced by high contents of vitamins, minerals, easily digestible carbohydrates, dietary fibers and pectin (Jensen et al. 2009; Ferretti et al. 2014).

Cultivars that have fruits able to retain their useful properties for a long time while being suitable for processing, are considered to be particularly valuable (Conceição de Oliveira et al. 2003; Lee \& Chan 2011). A good balance between marketable and consumer fruit qualities is an important characteristic of the cultivar used in breeding programs. Apples assigned for fresh consumption and for processing should meet certain requirements. The dessert quality of the fruits is primarily determined by harmonious taste, which depends mainly on the interrelation of sugars and acids (Harker et al. 2002). The essential traits needed for industrial processing of apples for concentrates, juices, puree, and dried fruits are the content of organic acids, pectins and polyphenolic substances (Nótin et al. 2011).

The assortment of apple orchards in Ukraine is enriched with new cultivars every year, including those bred at the Institute of Horticulture of the $\mathrm{Na}$ tional Academy of Agrarian Sciences of Ukraine (NAAS). The new cultivars possess a number of valuable traits, in particular immunity or resistance to fungal diseases, excellent taste and high storability. There is also a trend to grow organically regional cultivars better adapted to local climatic and soil conditions in which they can optimally develop their traits (Hecke et al. 2006). Here, we present results of a field experiment aimed at characterizing the physical (mass, size, pulp density) and biochemical (dry matter, soluble solids, sugars, organic acids, vitamin C, pectins, polyphenols) fruit quality of the apple cultivars bred in Ukraine to determine their suitability for fresh consumption and processing.

\section{MATERIALS AND METHODS}

During 2016-2019 the fruits of 13 apple cultivars - autumn cultivars 'Teremok', 'Skifs'ke Zoloto', 'Amulet', and winter cultivars 'Kateryna', 'Perlyna Kyieva', 'Ornament', 'Harant', 'Edera', 'Radohost', 'Todes', 'Askol'da', 'Dmiana', 'Solomiya' - that were bred by the Institute of Horticulture of NAAS were evaluated. The experiment was performed in the Western Forest-Steppe, aiming to select cultivars that are the most adapted to these conditions and of high consumer quality.

The climate of the Western Forest-Steppe of Ukraine is moderately continental, characterized by sufficient moisture. The mean air average temperature in January is $-6{ }^{\circ} \mathrm{C}$, in July $+19.5^{\circ} \mathrm{C}$, and for the period of growth and development of apple fruits is $18.6^{\circ} \mathrm{C}$ (based on long-term data). In 2016 this index was similar to long-term data: $18.5^{\circ} \mathrm{C}$, and was higher by $0.6,1.6$ and $2.0^{\circ} \mathrm{C}$ in 2017,2018 and 2019 , respectively. The specified period was the most humid in 2018, with $229.13 \mathrm{~mm}$ of precipitation, but that still was $91.87 \mathrm{~mm}$ less than the long-term average. The period of fruit growth and development in 2019 was characterized by the least moisture: $111.77 \mathrm{~mm}$. The sum of active temperatures of $10^{\circ} \mathrm{C}$ and above during the period of growth and development of apple fruits was $2807.0^{\circ} \mathrm{C}$ in 2016 , $2537.7^{\circ} \mathrm{C}$ in $2017,2749.3^{\circ} \mathrm{C}$ in 2018 and $2798.1^{\circ} \mathrm{C}$ in 2019. The ratio of precipitation amount to the sum of active temperatures $\geq 10^{\circ} \mathrm{C}$ was in the range from 0.4 in 2019 to 0.8 in 2018 with intermediate values of 0.5 in 2017 and 0.6 in 2016.

The soil of the plot is forest gray, loamy, the humus content is $2.3-3.5 \%$, pH 5.9-6.7. Fertilization of the orchard with nitrogen was carried out in early spring, and with phosphorus and potassium in late July. The rate of application was calculated based on the results of leaf diagnostics. Calcium chloride was applied 4 times foliarly during the growing season in the total amount of $55 \mathrm{~kg} \cdot \mathrm{ha}^{-1}$. The orchard was protected from pests and phytopathogenic organisms according to the integrated system common to the region of cultivation. 
The apple orchard from which the fruits were collected for analysis was planted in 2010, in a $5 \times 3 \mathrm{~m}$ scheme of. Trees were grafted on 54-118 clonal rootstock, and canopies shaped with central leader. Pruning of the trees was carried out annually.

Apple fruits for analysis, with a characteristic shape and color for the cultivar, were selected during fruit picking, at harvest ripeness. The degree of ripeness of the fruits was determined by the iodinestarch test. The degree of starch degradation in the studied cultivars was at the level of 6-6.5 points on a 9-point scale. Each sample had $2 \mathrm{~kg}$ of fruits. All studies were conducted in the Laboratory of Postharvest Quality of Fruit and Berry Products of the Institute of Horticulture of the National Academy of Agrarian Sciences of Ukraine.

\section{Physical indicators}

The average fruit mass was determined by weighing on laboratory scales with the precision of $0.05 \mathrm{~g}$; maximum diameter of the equatorial dimension was measured with sliding calipers; flesh firmness was evaluated with Wagner FRUIT TEST portable penetrometer with FT 30 FT716 nozzle, the diameter of $11 \mathrm{~mm}$. Ten fruits of each cultivar were used for analysis.

\section{Biochemical indicators}

The segments of equal size were cut at the four sides of the fruit in the longitudinal direction and ground using the laboratory homogenizer in order to prepare an analytical sample. The samples were weighed with an accuracy of $0.005 \mathrm{~g}$.

The method of drying the sample to a constant weight at a temperature of $98-100{ }^{\circ} \mathrm{C}$ was applied to establish the dry matter content; and the refractometric method to determine soluble solids content (Kondratenko et al. 2008).

\section{Organic titrated acids}

In order to extract the acids, $25 \mathrm{~g}$ of the ground sample were transferred into a $250 \mathrm{ml}$ volumetric flask with not more than $150 \mathrm{ml}$ of hot distilled water. The flask was kept in the water bath for 30 min at $80^{\circ} \mathrm{C}$ and cooled. The content of the flask was made up to $250 \mathrm{ml}$ with distilled water and filtered through a filter into a conical flask, into which $20 \mathrm{ml}$ of the extract were transferred with a pipette, and then 3-4 drops of phenolphthalein were added, titrated with $0.1 \mathrm{~N}$ sodium hydroxide until a pink color appeared, which corresponds to a $\mathrm{pH}$ of 7.0. At least two parallel measurements were carried out and the average value of the index was determined. The content of titrated acids in the sample was calculated using the formula with the index of the titer of $0.1 \mathrm{~N}$ sodium hydroxide and coefficient of the recapitulation for malic acid (Kondratenko et al. 2008).

\section{Ascorbic acid}

In order to extract ascorbic acid, the batch was ground in a porcelain mortar with the addition of broken glass and a mixture of $2 \%$-oxalic acid and $1 \%$-hydrochloric acid $(80+20$, vol + vol $)$ and transferred to a $100 \mathrm{ml}$ volumetric flask and filtered. The obtained extraction was titrated with a solution of 2,6-dichlorophenolindophenol (Tillman's paint). The ascorbic acid content in the sample was calculated using the formula applying the index of the titer of the Tillman's paint (Kondratenko et al. 2008).

\section{Sugars}

The extraction of the sugars from the fruits was conducted using hot distilled water. The obtained extract was purified from the proteins and pigments by precipitating them with the acetic plumbum. Sucrose was subjected to hydrolysis to glucose and fructose by heating in the presence of $10 \%$ hydrochloric acid. Hydrolysis products were oxidized with the Fehling solution. The optical density of the obtained solutions was established using a KFK-3-0.1 spectrophotometer at the wavelength of $640 \mathrm{~nm}$. Sugar content in the sample was calculated using the formula applying the indicator of the calibration graph. The standard glucose solutions with different concentrations were used for the formation of the calibration graph of optical density (units of optical density) dependence on glucose concentration (mg per $\mathrm{ml}$ ) (Voznesenskyi et al. 1962; Jermakov 1987).

\section{The sugar-acid index}

The sugar-acid index (SAI) was determined as the ratio of total sugar content to titrated acids content.

\section{Pectic substances}

In order to determine pectin content, the sample was purified from sugars and pigments with ethyl alcohol. 
The extraction of soluble pectin was carried out with water, and of protopectin - with $1 \mathrm{~N}$ sulfuric acid, hydrolysis of the latter to galacturonic acid - with heating. The $0.2 \%$-carbazole solution was added to the extraction of the soluble pectin and protopectin acidified with the concentrated sulfuric acid in order to form a colored complex. The optical density of the attained solutions was determined using a KFK-3-0.1 spectrophotometer at the wavelength of $535 \mathrm{~nm}$. The content of soluble pectin and protopectin in the sample was calculated using the coefficient of the recapitulation for apple pectin and indices of the calibration graph. The standard solutions of the galacturonic acid with different concentrations were applied for the formation of the calibration graph of the optical density (unit of the optical density) dependence on the mentioned acid concentration ( $\mu \mathrm{g}$ per $\mathrm{ml}$ ) (Voznesenskyi et al. 1962; Jermakov 1987).

\section{Polyphenolic substances}

In order to extract the polyphenols, the sample was ground in a porcelain mortar with a small amount of ethyl alcohol and filtered under the vacuum on a Buchner funnel into the Bunsen flask through the blue-tape paper filter, on which the rest was rinsed in small amounts of ethyl alcohol until the complete sample decolorization. The volume of alcohol used (in $\mathrm{ml}$ ) was noted. $7.9 \mathrm{ml}$ of the distilled water, $0.1 \mathrm{ml}$ of the extract, and $1 \mathrm{ml}$ of the Folin-Denis reagent were flowed into the vial, mixed, $1 \mathrm{ml}$ of the saturated sodium carbonate solution was added in 3 minutes and mixed again. After an hour, the optical density of the vial content was determined using KFK-3-0.1 spectrophotometer at the wavelength of $640 \mathrm{~nm}$. As the control, the mixture was prepared as follows: $8 \mathrm{ml}$ of distilled water and $1 \mathrm{ml}$ of the Folin-Denis reagent were flowed into the vial, mixed, $1 \mathrm{ml}$ of the saturated sodium carbonate solution was added in 3 minutes and mixed again. No less than 3 parallel measurements were conducted and the average value of the optical density was determined. Content of the polyphenolic substances in the sample was calculated applying the indicators of the calibration graph. The standard solutions of chlorogenic acid with different concentrations were used for the formation of the calibration graph of the optical density (optical density unit) dependence on the abovementioned acid concentration ( $\mu \mathrm{g}$ per $\mathrm{ml}$ ) (Voznesenskyi et al. 1962; Jermakov 1987).

\section{Statistical analysis}

Statistical analysis of the research data was carried out using STATISTICA 13.1 (StatSoft, USA) software. The results were presented in the form of mean values with their standard errors $(x \pm S E)$. The Shapiro-Wilk test was used to evaluate the assumptions of normality and homogeneity of variances. The significant differences between the means were determined by applying one-way ANOVA analysis. The results were presented at a level of reliability of $p<0.05$.

\section{RESULTS AND DISCUSSION}

\section{Physical indicators}

\section{Maximum diameter of the equatorial dimen- sion}

According to the requirements of the inland and international standards, apple fruits are divided into three grades depending on the maximum diameter of the equatorial dimension. In particular, the fruits with the mentioned index of not less than $70 \mathrm{~mm}$ are classified as the highest commercial grade, not less than $65 \mathrm{~mm}$ as the first grade. The mean value of the maximum diameter of the equatorial dimension among all investigated cultivars was $72.5 \mathrm{~mm}$, while the corresponding index for 'Amulet', 'Skifs'ke Zoloto', 'Todes', 'Askol'da', 'Perlyna Kyieva', 'Edera', and 'Teremok' was higher (from $78.0 \mathrm{~mm}$ to $72.0 \mathrm{~mm}$ ) (Table 1). 'The fruits of 'Dmiana' were the smallest with the maximum diameter of $65.0 \mathrm{~mm}$. (Table 1). 'Ornament', 'Harant' and 'Kateryna' had the highest variability of fruit diameter (CV 10-15.7\%) caused by weather conditions of the years studied. The impact of growing conditions on physical indices of fruit quality is common knowledge. Fukuda and Moriyama (1997) showed the dependence of apple fruit quality on their morphological peculiarities; the size and mass of early ripening cultivars are determined not only by the number of cells, but also their size, while the late ripening cultivars are determined by the number of cells only. 
Table 1. Physical characteristics of apple fruits' presented are averages for 2016-2019 ( $n=4)$

\begin{tabular}{|c|c|c|c|c|c|c|}
\hline \multirow{2}{*}{ Cultivar } & \multicolumn{2}{|c|}{$\begin{array}{l}\text { Maximum diameter of the } \\
\text { equatorial dimension }\end{array}$} & \multicolumn{2}{|c|}{ Fruit mass } & \multicolumn{2}{|c|}{ Flesh firmness } \\
\hline & $\mathrm{mm}$ & $\begin{array}{l}\mathrm{CV} \\
(\%)\end{array}$ & $\mathrm{G}$ & $\begin{array}{l}\mathrm{CV} \\
(\%)\end{array}$ & $\mathrm{kg}$ per $\mathrm{cm}^{2}$ & $\begin{array}{l}\mathrm{CV} \\
(\%)\end{array}$ \\
\hline 'Teremok' & $76.3 \pm 0,3^{\mathrm{a}}$ & 3.8 & $164.3 \pm 9.7$ & 6.0 & $7.7 \pm 0.3^{b}$ & 3.3 \\
\hline 'Skifs'ke Zoloto' & $77.5 \pm 5.9$ & 9.5 & $171.7 \pm 13.9$ & 22.2 & $7.4 \pm 0.5^{\mathrm{b}}$ & 10.6 \\
\hline 'Amulet' & $78.0 \pm 3.5$ & 5.0 & $189.4 \pm 20.4$ & 12.3 & $7.7 \pm 0.3^{\mathrm{b}}$ & 4.4 \\
\hline 'Kateryna' & $66.0 \pm 8.0$ & 12.3 & $158.2 \pm 3.4$ & 1.9 & $8.7 \pm 0.6$ & 6.6 \\
\hline 'Perlyna Kyieva' & $75.0 \pm 5.5$ & 9.2 & $191.4 \pm 17.9$ & 12.6 & $11.0 \pm 0.5^{\mathrm{a}}$ & 4.5 \\
\hline 'Ornament' & $69.0 \pm 12.2^{\mathrm{b}}$ & 15.7 & $172.7 \pm 25.8$ & 13.3 & $9.2 \pm 0.4$ & 4.9 \\
\hline 'Harant' & $76.3 \pm 4.6$ & 10.0 & $178.3 \pm 23.9$ & 11.9 & $9.2 \pm 0.1$ & 16 \\
\hline 'Edera' & $72.0 \pm 3.8$ & 6.6 & $168.2 \pm 9.0$ & 10.9 & $9.6 \pm 0.7$ & 9.4 \\
\hline 'Radohost' & $70.0 \pm 3.6$ & 7.9 & $147.4 \pm 13.8$ & 14.3 & $8.3 \pm 0.3$ & 4.6 \\
\hline 'Todes' & $76.0 \pm 4.5$ & 6.0 & $199.7 \pm 25.7$ & 13.1 & $9.6 \pm 0.2$ & 2.4 \\
\hline 'Askol'da' & $76.0 \pm 1.6$ & 3.5 & $180.6 \pm 9.8$ & 9.2 & $8.1 \pm 0.4$ & 6.7 \\
\hline 'Dmiana' & $65.0 \pm 6.8$ & 9.2 & $111.9 \pm 28.9^{\mathrm{b}}$ & 22.8 & $10.9 \pm 1.0^{\mathrm{a}}$ & 8.9 \\
\hline 'Solomiya' & $70.0 \pm 5.7$ & 5.2 & $148.8 \pm 14.9$ & 8.8 & $11.1 \pm 0.7^{\mathrm{a}}$ & 8.5 \\
\hline SE & 2.5 & & 26.0 & & 0.7 & \\
\hline $\mathrm{x}$ & 72.5 & & 169.5 & & 9.1 & \\
\hline
\end{tabular}

a;b are values of the indices that differ significantly from the mean $(x)$ for the studied group at $\mathrm{P}<0.05$

\section{Fruit mass}

The fruits of the studied cultivars accumulated mass ranging from $111.9 \mathrm{~g}$ ('Dmiana') to $199.7 \mathrm{~g}$ ('Todes'). The variability of the fruit mass of 'Dmiana' was high and differed significantly from the mean for the group by this parameter. The apples of 'Skifs'ke Zoloto', 'Amulet', 'Perlyna Kyieva', 'Ornament', 'Harant', 'Todes' and 'Askol'da' had a higher mass than the mean value of this index for the studied group (169.5 g), from $171.7 \mathrm{~g}$ to $199.7 \mathrm{~g}$. 'Skifs'ke Zoloto' and 'Dmiana' were unstable for this trait (CV 22.2\% and $22.8 \%$ respectively) whereas this index for 'Teremok', 'Kateryna', 'Askol'da' and 'Solomiya' was from $1.9 \%$ to $9.2 \%$ was constant and did not depend on the growing conditions. In the research carried out by Mitre et al. (2009) apple fruit mass varied from $117.0 \mathrm{~g}$ to $185.5 \mathrm{~g}$.

\section{Flesh firmness}

Flesh firmness is one of the fruit structure characteristics. It is considered a key factor determining fruit ripening. The reduction of apple fruit's firmness can be attributed to the modification of cell walls, loss of turgor, and degradation of starch and pectin substances. The intensity of these transformations affects the apple fruit quality (Orosz-Tóth et al. 2019). Flesh firmness should be taken into account when selling fresh apples for processing and for cold storage (Vanoli et al. 2015). In our research, fruits of late autumn ripening cultivars 'Teremok', 'Amulet', 'Skifs'ke Zoloto' had flesh firmness from 7.4 to $7.7 \mathrm{~kg} \mathrm{~cm}^{-2}$, which is less than the mean value of this index for the whole group $\left(9.1 \mathrm{~kg} \mathrm{~cm}^{-2}\right)$. Among winter ripening cultivars, 'Solomiya', 'Perlyna Kyieva', 'Dmiana', 'Edera', 'Todes', 'Harant', 'Ornament', the flesh firmness was higher than the mean for the group - from $11.1 \mathrm{~kg} \mathrm{~cm}^{-2}$ to $9.2 \mathrm{~kg} \mathrm{~cm}^{-2}$ for 'Kateryna', 'Radohost' and 'Askol'da' this index was lower - from $8.7 \mathrm{~kg} \mathrm{~cm}^{-2}$ to $8.1 \mathrm{~kg} \mathrm{~cm}^{-2}$ and the coefficients of variation varying from $1.6 \%$ ('Harant') to 9.4\% ('Edera') (Table 1). The fruits of the scab-resistant cultivars grown in Hungary had flesh firmness of $5.9-9.6 \mathrm{~kg} \mathrm{~cm}^{-2}$ (Orosz-Tóth et al. 2002). The maximum values of this index for Hungarian apples corresponded to the mean one calculated by us for the Ukrainian cultivars.

The fruits of the apple cultivars evaluated here growing in nonirrigated conditions have the maximum diameter of the equatorial dimension and fruit mass that meet the requirements of international and inland standards and flesh during harvest maturity varying from $7.4 \mathrm{~kg} \mathrm{~cm}^{-2}$ to $11.1 \mathrm{~kg} \mathrm{~cm}^{-2}$. This is necessary for ensuring excellent apple storability. 


\section{Biochemical indices of the fruit quality Dry matter}

Dry matter (DM) of the fruits here evaluated varied from $15.8 \%$ ('Amulet' and 'Skifs'ke Zoloto') to $18.1 \%$ ('Harant' and 'Todes'), differing considerably from the mean value of this index for the group of thirteen cultivars (16.8\%); this exceeded standard error. Fruits of 'Edera', 'Ornament' and 'Radohost' accumulated dry matter at a level of mean value and above, namely: $17.1 \%, 17.2 \%$, and $17.5 \%$. The coefficients of variation (lower than 7\%) prove the stability of the DM content in the fruits of all the cultivars (Table 2). High DM content indicates their favorability for processing apple powders. These values did not differ compared with the results of the research of Oszmiański et al. (2018) (12.3-17.1\% of DM) and Palmer et al. (2010), (10.8\% for 'Royal Gala' and $20.1 \%$ for 'Scifresh').

\section{Soluble solids}

Apple fruits, grown in Pakistan, accumulated from $9.9 \%$ to $16.75 \%$ of soluble solids (SS) (Aziz et al. 2013). In our research, the lowest content of the SS was detected in the fruits of 'Todes', 'Kateryna' and 'Dmiana' (from $12.3 \%$ to $14.5 \%$ ) that did not differ from the mean value for the group (13.4\%) and exceeded the standard error. Fruits of 'Solomiya', 'Perlyna Kyieva' and 'Ornament' had the mean SS value for the group 13.7-14.6\% (Table 2).
Considering the high content of these substances and their stability (SV 1.4-8.7\%) under the conditions of the Western Forest-Steppe of Ukraine, fruits of the studied cultivars can be a good raw materials for making fruit powders for the juices.

\section{Sugars}

Total sugars content in the studied apple cultivars ranged from $9.8 \%$ ('Todes') to $11.6 \%$ while the mean value of this index for the group was $10.7 \%$. The highest sugar content in the fruits was scored in 'Perlyna Kyieva', 'Amulet', 'Kateryna' and 'Dmiana' (11.0$11.2 \%)$. Sugar content in the apples cultivated in the intensive orchards of Austria and Slovenia was 11.516.0\% (Hecke et al. 2006), and in Pakistan 7.5720.13\% (Aziz et al. 2013). Given indices had a greater range of variation between the minimum and maximum values. The results we obtained were within the data reported by Akagić et al. (2019) $7.1 \%$ to $8.5 \%$ of monosaccharides, while in our experiment the range was $7.0-10.2 \%$. The rest of the studied cultivars contained between $8.6 \%$ and $7.0 \%$. Reducing sugars content in the fruits of 'Kateryna' (10.2\%) and 'Ornament' (9.8\%) was maximum, and minimum for 'Dmiana' (7.6\%) and 'Solomiya' (7.0\%). Those indices differed considerably from the mean value for the group and were beyond the standard error. Cultivars 'Ornament', 'Todes', 'Edera' and 'Radohost' did not have a stable reduced sugars content during the years of the study, and CV was higher than $16.0 \%$ (Table 3).

Table 2. The content of dry matter and soluble solids in apple fruit, given are averages for 2016-2019 $(n=4)$

\begin{tabular}{|c|c|c|c|c|}
\hline \multirow[b]{2}{*}{ Cultivar } & \multicolumn{2}{|c|}{ Dry matter } & \multicolumn{2}{|c|}{ Soluble solids } \\
\hline & $\%$ & $\begin{array}{l}\mathrm{CV} \\
(\%)\end{array}$ & $\%$ & $\begin{array}{l}\mathrm{CV} \\
(\%)\end{array}$ \\
\hline 'Teremok' & $16.6 \pm 1.3$ & 6.9 & $12.8 \pm 0.7$ & 6.6 \\
\hline 'Skifs'ke Zoloto' & $15.8 \pm 0.4^{\mathrm{b}}$ & 2.5 & $13.1 \pm 0.5$ & 6.3 \\
\hline 'Amulet' & $15.8 \pm 0.4^{\mathrm{b}}$ & 2.0 & $13.5 \pm 0.5$ & 5.7 \\
\hline 'Kateryna' & $17.7 \pm 0.3^{\mathrm{a}}$ & 1.4 & $14.0 \pm 0.9^{\mathrm{a}}$ & 8.7 \\
\hline 'Perlyna Kyieva' & $16.7 \pm 0.5$ & 2.8 & $13.8 \pm 0.5$ & 4.9 \\
\hline 'Ornament' & $17.2 \pm 0.8$ & 4.3 & $14.6 \pm 0.9$ & 7.8 \\
\hline 'Harant' & $18.1 \pm 0.4^{\mathrm{a}}$ & 1.8 & $13.0 \pm 0.2$ & 6.8 \\
\hline 'Edera' & $17.1 \pm 1.3$ & 6.8 & $13.0 \pm 0.6$ & 7.7 \\
\hline 'Radohost' & $17.5 \pm 1.0$ & 4.8 & $13.3 \pm 0.5$ & 6.5 \\
\hline 'Todes' & $18.1 \pm 0.7^{\mathrm{a}}$ & 3.4 & $12.3 \pm 0.6^{b}$ & 4.6 \\
\hline 'Askol'da' & $16.1 \pm 0.4$ & 2.0 & $13.0 \pm 0.5$ & 6.5 \\
\hline 'Dmiana' & $15.5 \pm 0.6^{\mathrm{b}}$ & 4.1 & $14.5 \pm 0.2^{\mathrm{a}}$ & 1.4 \\
\hline 'Solomiya' & $15.9 \pm 0.5$ & 3.0 & $13.7 \pm 0.9$ & 2.0 \\
\hline $\mathrm{SE}$ & 0.5 & & 0.4 & \\
\hline $\mathrm{x}$ & 16.8 & & 13.4 & \\
\hline
\end{tabular}

\footnotetext{
a; $b$ are values of indicators that differ significantly from the average $(x)$ for the studied group at $P<0.05$
} 
Table 3. The content of organic matter in apple fruit, given are averages for 2016-2019 $(n=4)$

\begin{tabular}{|c|c|c|c|c|c|c|c|}
\hline \multirow[b]{2}{*}{ Cultivar } & \multicolumn{2}{|c|}{ Total sugars } & \multicolumn{2}{|c|}{ Monosaccharides } & \multicolumn{2}{|c|}{ Titrated acids } & \multirow{2}{*}{$\begin{array}{l}\text {-Sugar-acid } \\
\text { index }\end{array}$} \\
\hline & $\%$ & $\begin{array}{l}\mathrm{CV} \\
(\%)\end{array}$ & $\%$ & $\begin{array}{l}\mathrm{CV} \\
(\%)\end{array}$ & $\%$ & $\begin{array}{l}\mathrm{CV} \\
(\%)\end{array}$ & \\
\hline 'Teremok' & $10.4 \pm 0.8$ & 9.0 & $9.1 \pm 0.7$ & 12.2 & $0.51 \pm 0.10$ & 27.4 & 20 \\
\hline 'Skifs'ke Zoloto' & $10.5 \pm 0.4$ & 6.0 & $8.7 \pm 0.7$ & 14.4 & $0.52 \pm 0.08$ & 26.9 & 20 \\
\hline 'Amulet' & $11.2 \pm 0.8$ & 11.0 & $8.7 \pm 0.5$ & 8.3 & $0.48 \pm 0.10$ & 33.3 & 23 \\
\hline 'Kateryna' & $11.2 \pm 0.7$ & 8.1 & $10.2 \pm 1.2^{\mathrm{a}}$ & 12.9 & $0.45 \pm 0.10$ & 8.8 & 25 \\
\hline 'Perlyna Kyieva' & $11.0 \pm 0.4$ & 4.8 & $8.9 \pm 0.5$ & 9.2 & $0.54 \pm 0.15$ & 27.8 & 20 \\
\hline 'Ornament' & $11.6 \pm 0.7^{\mathrm{a}}$ & 7.5 & $9.8 \pm 1.6^{\mathrm{a}}$ & 21.2 & $0.41 \pm 0.05^{\mathrm{b}}$ & 14.6 & 28 \\
\hline 'Harant' & $10.5 \pm 0.6$ & 6.9 & $8.2 \pm 1.1$ & 14.3 & $0.63 \pm 0.12$ & 17.4 & 17 \\
\hline 'Edera' & $10.4 \pm 0.5$ & 7.8 & $7.9 \pm 0.9$ & 17.0 & $0.55 \pm 0.06$ & 18.1 & 20 \\
\hline 'Radohost' & $10.6 \pm 0.4$ & 6.6 & $8.6 \pm 1.0$ & 17.3 & $0.68 \pm 0.09$ & 20.5 & 16 \\
\hline 'Todes' & $9.8 \pm 0.4^{b}$ & 4.6 & $8.4 \pm 1.1$ & 16.7 & $0.79 \pm 0.12^{\mathrm{a}}$ & 15.1 & 12 \\
\hline 'Askol'da' & $10.4 \pm 0.4$ & 6.2 & $8.6 \pm 0.6$ & 11.6 & $0.58 \pm 0.05$ & 15.5 & 18 \\
\hline 'Dmiana' & $11.2 \pm 0.8$ & 6.4 & $7.6 \pm 0.4^{b}$ & 5.1 & $0.48 \pm 0.08$ & 14.7 & 23 \\
\hline 'Solomiya' & $10.6 \pm 0.9$ & 7.2 & $7.0 \pm 0.6^{\mathrm{b}}$ & 7.5 & $0.67 \pm 0.18$ & 25.3 & 16 \\
\hline SE & 0.3 & & 0.4 & & 0.06 & & \\
\hline $\mathrm{x}$ & 10.7 & & 8.6 & & 0.56 & & 20 \\
\hline
\end{tabular}

Note: see Table 2

\section{Titrated acids (TA)}

Titrated acidity is an important index for apple fruit evaluation (Lo Piccolo et al. 2019). Apple cultivars grown widely throughout the world accumulate titrated acidity at a level of $0.57-1.50 \%$ (Wang et al. 2019). In the Western Forest-Steppe of Ukraine, the highest amount of these substances was accumulated by the fruits of 'Todes' $(0.79 \%)$, and the lowest by 'Ornament' $(0.41 \%)$; the mean value for these cultivars was $0.56 \%$. The stability of this index in the fruits of the mentioned cultivars was average, proved by $\mathrm{CV}$ of $15.1 \%$ and $14.6 \%$, respectively. The most variable (CV above $26.9 \%$ ) while being lower than the mean value, was the content of the organic acids in the fruits of 'Skifs'ke Zoloto', 'Teremok', 'Perlyna Kyieva', and 'Amulet' (from $0.54 \%$ to $0.48 \%$ ). High acid content in the fruits of 'Solomiya' $(0.67 \%)$ was not stable (CV 25.3\%) (Table 3).

\section{Sugar acid index (SAI)}

The ratio between the content of sugars and acids affects the taste, aroma, and further use of the apple fruit (Wu et al. 2007; Mikulic Petkovsek et al. 2010; Wang et al. 2019). The above-mentioned substances are the main determinants of the fruit organoleptic quality (Ma et al. 2019). The sweet taste of apples is determined by large sugars content, while sour taste is determined by the content of titrated acids (Pochitskaya et al. 2019). The fruits with SAI lower than 20 have a strong sharp taste and are suitable for processing, including making cider; those with SAI above 20 are considered dessert and suitable for fresh consumption (Lee et al. 2003). Cultivars bred in Ukraine have a mean SAI of 20, with the highest value of 28 ('Ornament') and the lowest one of 12 ('Todes'). SAI of the fruits of ' Kateryna', 'Amulet' and 'Dmiana' was higher than the mean value for the group ( 25 and 23, respectively). That is an indicator of their harmonious and balanced taste. The fruits of 'Teremok', 'Skifs'ke Zoloto', 'Perlyna Kyieva' and 'Edera' have SAI values at the mean level for the group. These cultivars are of universal purpose and can be consumed both fresh and processed. The fruits of cultivars with SAI lower than 20, namely 'Harant', 'Radohost' and 'Solomiya', can be used for making cider if picked at harvest maturity (Table 3). Lee (2003) stated that the cultivars with SAI lower than 20 can be regarded as cider cultivars. 


\section{Pectic substances (PS)}

Pectins are necessary for the human body. As polyelectrolytes, gel formers and emulsifiers, they are used in medicine for the treatment and prevention of various diseases, as well as in the food industry (Pavel \& Makarkina 2018). PS content in apple fruits is $0.3-2.4 \%$ of the raw mass (Shyrko \& Jaroshevych et al. 1991; Dadashev et al. 2000; Potkina et al. 2016). More than $1.0 \%$ of PS was accumulated by the fruits of almost all Ukrainian cultivars studied here, except for 'Askol'da', 'Skifs'ke Zoloto' and 'Amulet' (from $0.93 \pm 0.12 \%$ to $0.97 \pm 0.19 \%$ ). Fruits of 'Perlyna Kyieva', 'Edera', 'Solomiya', 'Ornament', 'Harant' and 'Radohost' had PS values comparable to the mean value of this index for the group (1.04\%). Fruits of 'Radohost' had the highest PS among the researched cultivars, beyond the standard error. The fruits of resistant cultivars of Belarus origin are able to accumulate from $0.76 \%$ ('Zorka') to $1.31 \%$ ('Navavita') of pectin substances (Kazlouskaya \& Yarmolich 2019), and those grown in Pakistan - 0.10-1.3\% (Aziz et al. 2013). That is comparable to the data obtained in our research. Fruits of 'Ornament', 'Dmiana' and 'Kateryna' (CV 9.8\%, 12.1\% and 13.1\%, respectively) cultivars distinguished themselves for the stability of the PS content among the studied group. The rest of the cultivars were characterized with average and low stability of PS content (Table 4). The steadily large amount of the pectin substances (more than $1 \%$ ), in the fruits of 'Kateryna', 'Ornament', 'Dmiana' and 'Solomiya' is the indicator of their high gel capacity, and fruits of the mentioned cultivars may be used for making high-sugar preserves and for pectin production.

\section{Ascorbic acid}

Ascorbic acid (AA) is the most known prophylactic vitamin (Baron 2009). In addition, it helps in many processes, being a cofactor for mono- and dioxygenases and histone demethylases as well as an intensifier of iron absorption in the human organism (Di Matteo et al. 2010; Truffault et al. 2017; Granger \& Eck 2018). The daily intake of AA should be 30 $250 \mathrm{mg}$ depending on the age, employment, and health condition of the person (NIH 2019). Apple fruits do not synthesize large amounts of AA due to their physiological and morphological peculiarities.
For example, AA content in apple fruits from Pakistan is $1.3-7.38 \mathrm{mg} \cdot 100 \mathrm{~g}^{-1}$ (Aziz et al. 2013), and from Germany $5.5-13.4 \mathrm{mg} \cdot 100 \mathrm{~g}^{-1}$ (Kschonsek et al. 2018). AA content in the fruits of studied Ukrainian cultivars varies from $3.8 \mathrm{mg} \cdot 100 \mathrm{~g}^{-1}$ ('Solomiya') to $11.5 \mathrm{mg} \cdot 100 \mathrm{~g}^{-1}$ ('Harant'). The C-vitamin potency of the latter cultivar is significantly higher compared to others and is beyond the standard error. It was stated that even such low vitamin $C$ content is enough to contribute to better availability of the P-active substances (Granger \& Eck 2018). Among the evaluated cultivars, only 'Harant' had high AA $\left(11.5 \mathrm{mg} \cdot 100 \mathrm{~g}^{-1}\right)$ content with the coefficient of variation being 7.9\%. Fruits of 'Askol'da', 'Todes' and 'Kateryna' accumulated $6.1 \mathrm{mg} \cdot 100 \mathrm{~g}^{-1}$ to $6.7 \mathrm{mg} \cdot 100 \mathrm{~g}^{-1}$ of the AA, which is higher than the average value for the investigated group of cultivars $\left(5.7 \mathrm{mg} \cdot 100 \mathrm{~g}^{-1}\right)$. AA content in the fruits of the rest of the cultivars changes substantially depending on the year (Table 4).

\section{Polyphenolic compounds (PC)}

Apple polyphenols are potent acceptors of free radicals, like antioxidants and antiphlogistics drugs (Ferretti et al. 2014). Apple fruits' antioxidant properties are mostly connected with a high amount of flavonoids, or, more precisely, of catechin and epicatechin, in the skin and pulp (Hyson 2011; Pei et al. 2016). Our results have shown that PC content in the fruits of cultivars bred in Ukraine fluctuated from $127 \mathrm{mg} \cdot 100 \mathrm{~g}^{-1}$ ('Todes') to $262 \mathrm{mg} \cdot 100 \mathrm{~g}^{-1}$ ('Solomiya'), while for Canadian cultivars it ranged from $99 \mathrm{mg} \cdot 100 \mathrm{~g}^{-1}$ to $451 \mathrm{mg} \cdot 100 \mathrm{~g}^{-1}$ (Khanizadeh et al. 2008). In the apples grown in Hungary the range was from $194 \mathrm{mg} \cdot 100 \mathrm{~g}^{-1}$ to $479 \mathrm{mg} \cdot 100 \mathrm{~g}^{-1}$ (Ficzek et al. 2013), and in Germany from $99.6 \mathrm{mg} \cdot 100 \mathrm{~g}^{-1}$ to $495.3 \mathrm{mg} \cdot 100 \mathrm{~g}^{-1}$ of the raw mass (Kschonsek et al. 2018). In our cultivars the mean PC content was $206 \mathrm{mg} \cdot 100 \mathrm{~g}^{-1}$ of the raw mass; higher contents from 209 to $262 \mathrm{mg} \cdot 100 \mathrm{~g}^{-1}$ were accumulated in the fruits of eight cultivars. Two cultivars were characterized with high polyphenolic stability (CV 7.4\% and $13.0 \%$, respectively) but 'Harant' was characterized by high variability of this trait (CV 26.0\%). PC content in the fruits of 'Solomiya', 'Amulet', 'Todes' and 'Harant' is beyond the standard error and differed significantly from the mean value for this group of cultivars (Table 4). 
Table 4. The content of biologically active substances in apple fruits, given are averages for 2016-2019 (n=4)

\begin{tabular}{|c|c|c|c|c|c|c|}
\hline \multirow{2}{*}{ Cultivar } & \multicolumn{2}{|c|}{ Pectic substances } & \multicolumn{2}{|l|}{ Ascorbic acid } & \multicolumn{2}{|l|}{$\begin{array}{c}\text { Polyphenolic } \\
\text { substances }\end{array}$} \\
\hline & $\%$ & $\begin{array}{l}\mathrm{CV} \\
(\%)\end{array}$ & $\mathrm{mg}$ per $100 \mathrm{~g}$ of fresh weight & $\begin{array}{l}\mathrm{CV} \\
(\%)\end{array}$ & $\mathrm{mg}$ per $100 \mathrm{~g}$ of fresh weight & $\begin{array}{l}\mathrm{CV} \\
(\%)\end{array}$ \\
\hline 'Teremok' & $1.01 \pm 0.18$ & 22.0 & $5.4 \pm 1.8$ & 44.4 & $210 \pm 14$ & 7.4 \\
\hline 'Skifs'ke Zoloto' & $0.96 \pm 0.23$ & 24.6 & $4.6 \pm 0.8$ & 28.1 & $195 \pm 35$ & 20.4 \\
\hline 'Amulet' & $0.97 \pm 0.19$ & 26.6 & $3.9 \pm 0.8$ & 29.7 & $165 \pm 19^{a}$ & 17.6 \\
\hline 'Kateryna' & $1.04 \pm 0.15$ & 13.1 & $6.7 \pm 1.5$ & 19.4 & $245 \pm 33$ & 15.3 \\
\hline 'Perlyna Kyieva' & $1.05 \pm 0.25$ & 32.1 & $3.9 \pm 1.1$ & 44.1 & $194 \pm 17$ & 11.5 \\
\hline 'Ornament' & $1.07 \pm 0.12$ & 9.8 & $4.5 \pm 1.4$ & 26.8 & $217 \pm 35$ & 16.3 \\
\hline 'Harant' & $1.24 \pm 0.21$ & 15.3 & $11.5 \pm 1.0^{\mathrm{a}}$ & 7.9 & $133 \pm 39^{\mathrm{a}}$ & 26.0 \\
\hline 'Edera' & $1.05 \pm 0.12$ & 16.4 & $5.6 \pm 1.2$ & 33.5 & $209 \pm 32$ & 20.3 \\
\hline 'Radohost' & $1.14 \pm 0.16^{\mathrm{a}}$ & 18.5 & $5.4 \pm 0.8$ & 18.8 & $241 \pm 43$ & 18.0 \\
\hline 'Todes' & $1.03 \pm 0.28$ & 27.5 & $6.4 \pm 1.7$ & 26.2 & $127 \pm 16^{\mathrm{a}}$ & 10.8 \\
\hline 'Askol'da' & $0.93 \pm 0.12$ & 17.9 & $6.1 \pm 1.2$ & 31.0 & $256 \pm 23$ & 13.0 \\
\hline 'Dmiana' & $1.02 \pm 0.14$ & 12.1 & $4.3 \pm 1.5$ & 32.0 & $224 \pm 44$ & 38.6 \\
\hline 'Solomiya' & $1.07 \pm 0.20$ & 7.6 & $3.8 \pm 0.9$ & 20.0 & $262 \pm 24^{\mathrm{b}}$ & 21.4 \\
\hline SE & 0.04 & & 2.5 & & 23 & \\
\hline $\mathrm{x}$ & 1.04 & & 5.7 & & 206 & \\
\hline
\end{tabular}

Note: see Table 1

\section{CONCLUSIONS}

Apple fruits of all evaluated cultivars are suitable for fresh consumption. Fruits of 'Teremok', 'Skifs'ke Zoloto', 'Perlyna Kyieva', and 'Edera' are of universal purpose, can be consumed fresh, and are a good raw material for the production of natural juice and puree. Cider can be made from 'Harant', 'Radohost' and 'Solomiya' fruits. The stable high amount of pectin, more than $1 \%$, in the fruits of 'Kateryna', 'Ornament', 'Dmiana' and 'Solomiya' is an indicator of their good gelling ability, which proves their suitability for making jams, marmalades, as well as a raw material for pectin production.

\section{REFERENCES}

Akagić A., Vranac A., Gaši F., Drkenda P., Spaho N., Oručević Žuljević S. et al. 2019. Sugars, acids and polyphenols profile of commercial and traditional apple cultivars for processing. Acta Agriculturae Slovenica 113(2): 239-250. DOI: 10.14720/aas.2019.113.2.5.

Ali M.A., Raza H., Khan M.A., Hussain M. 2004. Effect of different periods of ambient storage on chemical composition of apple fruit. International Journal of Agriculture and Biology 6: 568-571.
Amiri M.E., Fallahi E., Safi-Songhorabad M. 2014. Influence of rootstock on mineral uptake and scion growth of 'Golden Delicious' and 'Royal Gala' apples. Journal of Plant Growth Nutrition 37(1): 1629. DOI: $10.1080 / 01904167.2013 .792838$.

Aziz M., Jadoon S., Sh Z. 2013. Apples pulp (Pyrus malus) nutritional profiling evaluation of various varieties of Balochistan. Pakistan Journal of Nutrition 12(3): 239-243. DOI: 10.3923/pjn.2013.239.243.

Baron J.H. 2009. Sailors' scurvy before and after James Lind - a reassessment. Nutrition Reviews 67(6): 315-332. DOI: 10.1111/j.1753-4887.2009.00205.x.

Ciesa F., Dalla Via J., Wisthaler A., Zanella A., Guerra W., Mikoviny T. et al. 2013. Discrimination of four different postharvest treatments of 'Red Delicious' apples based on their volatile organic compound (VOC) emissions during shelf-life measured by proton transfer reaction mass spectrometry (PTRMS). Postharvest Biology and Technology 86: 329-336. DOI: 10.1016/j.postharvbio.2013.06.036.

Ciesa F., Höller I., Guerra W., Berger J., Dalla Via J., Oberhuber M. 2015. Chemodiversity in the fingerprint analysis of volatile organic compounds (VOCs) of 35 old and 7 modern apple cultivars determined by Proton-Transfer-Reaction Mass Spectrometry (PTR-MS) in two different seasons. Chemistry and Biodiversity 12(5): 800-812. DOI: 10.1002/cbdv.201400384. 
Conceição de Oliveira M., Sichieri R., Moura A.S. 2003. Weight loss associated with a daily intake of three apples or three pears among overweight women. Nutrition 19(3): 253-256. DOI: 10.1016/s0899-9007(02)00850-x.

Dadashev M.N., Vahydov Ya.A., Shykhnebyev D.A., Balyeva Zh.S. 2000. Perspektivy proizvodstva I primeneniya pektinovykh veshchestv. Khranenye I Pererabotka Selkhozsyria 9: 46-50. [in Russian]

Di Matteo A., Sacco A., Anacleria M., Pezzotti M., Delledonne M., Ferrarini A. et al. 2010. The ascorbic acid content of tomato fruits is associated with the expression of genes involved in pectin degradation. BMC Plant Biology 10; 163; 11 p. DOI: 10.1186/1471-2229-10-163.

Donno D., Beccaro G.L., Mellano M.G., Torello Marinoni D., Cerutti A.K., Canterino S., Bounous G. 2012. Application of sensory, nutraceutical and genetic techniques to create a quality profile of ancient apple cultivars. Journal of Food Quality 35(3): 169-181. DOI: 10.1111/j.1745-4557.2012.00442.x.

Fukuda H., Moriyama O. 1997. Relationship between cortical cell diameter, population and the harvest size of apple. Journal of the Japanese Society for Horticultural Science 66(1): 185-188. DOI: 10.2503/jjshs.66.185. [in Japanese with English abstract]

Faramarzi S., Pacifico S., Yadollahi A., Lettieri A., Nocera P., Piccolella S. 2015. Red-fleshed apples: Old autochthonous fruits as a novel source of anthocyanin antioxidants. Plant Foods for Human Nutrition 70(3): 324-330. DOI: 10.1007/s11130-015-0497-2.

Feliciano R.P., Antunes C., Ramos A., Serra A.T., Figueira M.E., Duarte C.M.M. et al. 2010. Characterization of traditional and exotic apple varieties from Portugal. Part 1 - Nutritional, phytochemical and sensory evaluation. Journal of Functional Foods 2(1): 35-45. DOI: 10.1016/j.jff.2009.12.004.

Ferretti G., Turco I., Bacchetti T. 2014. Apple as a source of dietary phytonutrients: Bioavailability and evidence of protective effects against human cardiovascular disease. Food and Nutrition Sciences 5(13): 1234-1246. DOI: 10.4236/fns.2014.513134.

Ficzek G., Ladányi M., Radeczky Zs., Tóth M. 2013. Healthcare values and potential uses of the new Hungarian apple varieties on the basis on fruit analysis. International Journal of Horticultural Science 19(3-4): 25-28. DOI: 10.31421/ijhs/19/3-4./1097.
Granger M., Eck P. 2018. Dietary vitamin C in human health. Advances in Food and Nutrition Research 83: 281-310. DOI: 10.1016/bs.afnr.2017.11.006.

Harker F.R., Marsh K.B., Young H., Murray S.H., Gunson F.A., Walker S.B. 2002. Sensory interpretation of instrumental measurements 2: sweet and acid taste of apple fruit. Postharvest Biology Technology 24(3): 241-250. DOI: 10.1016/s0925-5214(01)00157-0.

Hecke K., Herbinger K., Veberič R., Trobec M., Toplak H., Štampar F. et al. 2006. Sugar-, acid- and phenol contents in apple cultivars from organic and integrated fruit cultivation. European Journal of Clinical Nutrition 60(9): 1136-1140. DOI: 10.1038/sj.ejcn.1602430.

Hyson D.A. 2011. A comprehensive review of apples and apple components and their relationship to human health. Advances in Nutrition 2(5): 408-420. DOI: 10.3945/an.111.000513.

Jensen E.N., Buch-Andersen T., Ravn-Haren G., Dragsted LO. 2009. Mini-review: the effects of apples on plasma cholesterol levels and cardiovascular risk - a review of the evidence. Journal of Horticultural Science and Biotechnology 84(6): 34-41. DOI: 10.1080/14620316.2009.11512592.

Ermakov A.I. 1987. Methods of Biochemical Analysis of Plants. Kolos, Leningrad, 430 p. [in Russian]

Kazlouskaya Z.A, Yarmolich S.A. 2019. Biochemical composition of fruits of new apple varieties of Belarusian breeding. Horticulture and Viticulture 3: 5-12. DOI: 10.31676/0235-2591-2019-3-5-12. [in Russian with English abstract]

Khanizadeh S., Tsao R., Rekika D., Yang R., Charles M.T., Rupasinghe H.P.V. 2008. Polyphenol composition and total antioxidant capacity of selected apple genotypes for processing. Journal of Food Composition and Analysis 21(5): 396-401. DOI: 10.1016/j.jfca.2008.03.004.

Kondratenko P.V., Shevchuk L.M., Levchuk L.M. 2008. Methods of assessing the quality of fruit products. Kyiv, SPD Zhiteliev, 80 p. [in Ukrainian]

Kschonsek J., Wolfram T., Stöckl A., Böhm V. 2018. Polyphenolic compounds analysis of old and new apple cultivars and contribution of polyphenolic profile to the in vitro antioxidant capacity. Antioxidants 7(1); 20; 14 p. DOI: 10.3390/antiox7010020. 
Lee J.E., Chan A.T. 2011. Fruit, vegetables, and folate: cultivating the evidence for cancer prevention. Gastroenterology 141(1): 16-20. DOI: 10.1053/j.gastro.2011.05.020.

Lee K.W., Kim Y.J., Kim D.-O., Lee H.J., Lee C.Y. 2003. Major phenolics in apple and their contribution to the total antioxidant capacity. Journal of Agricultural and Food Chemistry 51(22): 6516-6520. DOI: 10.1021/jf034475w.

Lo Piccolo E., Viviani A., Guidi L., Remorini D., Massai R., Bernardi R., Landi M. 2019. Discerning between two Tuscany (Italy) ancient apple cultivars, 'Rotella' and 'Casciana', through polyphenolic fingerprint and molecular markers. Molecules 24(9); 1758; 15 p. DOI: 10.3390/molecules24091758.

Ma B., Ding Y., Li C., Li M., Ma F., Yuan Y. 2019. Comparative proteomic analysis reveals key proteins linked to the accumulation of soluble sugars and organic acids in the mature fruits of the wild Malus species. Plants 8(11); 488; 16 p. DOI: 10.3390/plants8110488.

Mikulic Petkovsek M., Slatnar A., Stampar F., Veberic R. 2010. The influence of organic/integrated production on the content of phenolic compounds in apple leaves and fruits in four different varieties over a 2 year period. Journal of the Science of Food and Agriculture 90(14): 2366-2378. DOI: 10.1002/jsfa.4093.

Mitre I., Mitre V., Ardelean M., Sestras R., Sestras A. 2009. Evaluation of old apple cultivars grown in Central Transylvania, Romania. Notulae Botanicae Horti Agrobotanici Cluj-Napoca 37(1): 235-237. DOI: $10.15835 /$ nbha3713127.

NIH 2019. Vitamin C Fact Sheet for Consumers. National Institutes of Health, Office of Dietary Supplements, USA, 3 p. https://ods.od.nih.gov/pdf/factsheets/VitaminC-Consumer.pdf (accessed October 05, 2019)

Nour V., Trandafir I., Ionica M.E. 2010. Compositional characteristics of fruits of several apple (Malus domestica Borkh.) cultivars. Notulae Botanicae Horti Agrobotanici Cluj-Napoca 38(3): 228-233. DOI: 10.15835/nbha3834762.

Nótin B., Stéger-Máté M., Juhász R., Ficzek G., Tóth M., Barta J. 2011. Effect of pre-treatment solutions of dried apple slices from several cultivars. Review of Faculty of Engineering, Analecta Technica Szegedinensia 2011(1-2): 129-137.
Orosz-Tóth M., Kincses S. 2002. Development of the antioxidant indexes (FRAP, TFC, TPC) of scabbing resistant apple varieties in storage. Acta Agraria Debreceniensis 1: 89-94. DOI: 10.34101/actaagrar/1/3775.

Orosz-Tóth M., Kincses S. 2019. The examination of flesh firmness in different apple varieties. Acta Agraria Debreceniensis 2: 103-107. DOI: 10.34101/actaagrar/2/3686.

Oszmiański J., Lachowicz S., Gławdel E., Cebulak T., Ochmian I. 2018. Determination of phytochemical composition and antioxidant capacity of 22 old apple cultivars grown in Poland. European Food Research and Technology 244: 647-662. DOI: 10.1007/s00217-017-2989-9.

Palmer J.W., Harker F.R., Tustin D.S., Johnston J. 2010. Fruit dry matter concentration: a new quality metric for apples. Journal of the Science of Food and Agriculture 90(15): 2586-2594. DOI: 10.1002/jsfa.4125.

Panzella L., Petriccione M., Rega P., Scortichini M., Napolitano A. 2013. A reappraisal of traditional apple cultivars from Southern Italy as a rich source of phenols with superior antioxidant activity. Food Chemistry 140(4): 672-679. DOI: 10.1016/j.foodchem.2013.02.121.

Pavel A.R., Makarkina M.A. 2018. The content of pectin substances and the stability feature of the new apple varieties cultivars developed at the VNIISPK. Contemporary Horticulture 1: 24-30. DOI: 10.24411/2312-6701-2018-10104. [in Russian with English abstract]

Pei K., Ou J., Huang J., Ou S. 2016. p-Coumaric acid and its conjugates: dietary sources, pharmacokinetic properties and biological activities. Journal of the Science of Food and Agriculture 96(9): 2952-2962. DOI: $10.1002 /$ jsfa.7578.

Pochitskaya I.M., Roslyakov Yu.F., Komarova N.V., Roslik V.L. 2019. Sensory components of fruits and berries Food Processing: Techniques and Technology 49(1): 50-61. DOI: 10.21603/2074-9414-2019-1-50-61. [in Russian with English abstract]

Potkina G., Lyashevskaya N., Kuznetzova O. 2016. Pectin substances of fruit-berry crops. Proceedings of the Scientific Conference "Biodiversity, problems of ecology of Gorny Altay and adjacent territory: present, past, future”. RIO GAGU, Gorno-Altaysk, Russia, 123 p. [in Russian] 
Shyrko T.S., Jaroshevych Y.V. 1991. Biokhimiya i kachestvo plodov. Navuka i Tekhnika. [in Russian] Skordas K., Papastergios G., Filippidis A. 2013. Major and trace element contents in apples from a cultivated area of central Greece. Environmental Monitoring and Assessment 185(10): 8465-8471. DOI: 10.1007/s10661-013-3188-1.

Truffault V., Fry S.C., Stevens R.G., Gautier H. 2017. Ascorbate degradation in tomato leads to accumulation of oxalate, threonate and oxalyl threonate. Plant Journal 89(5): 996-1008. DOI: 10.1111/tpj.13439.

Vanoli M., Rizzolo A., Grassi M., Torricelli A., Zanella A., Spinelli L. 2015. Characterizing apple texture during storage through mechanical, sensory and optical properties. Acta Horticulturae 1079: 383-390. DOI: 10.17660/actahortic.2015.1079.48.
Voznesenskyi V.L., Horbacheva H.Y, Shtanko T.P., Fylyppova L.A. 1962. Opredeleniye sakharov po obestsvechivaniyu zhidkosti Fellynha. Fiziologiya Rasteniy. [in Russian] Wang Y., Yang H., Zhong S., Liu X., Li T., Zong C. 2019. Variations in sugar and organic acid content of fruit harvested from different Vaccinium uliginosum populations in the Changbai Mountains of China. Journal of the American Society for Horticultural Science 144(6): 420-428. DOI: 10.21273/jashs04740-19.

Wolfe K., Wu X., Liu R.H. 2003. Antioxidant activity of apple peels. Journal of Agricultural and Food Chemistry 51(3): 609-614. DOI: 10.1021/jf020782a.

Wu J., Gao H., Zhao L., Liao X., Chen F., Wang Z., Hu Z. 2007. Chemical composition characterization of some apple cultivars. Food Chemistry 103(1): 8893. DOI: 10.1016/j.foodchem.2006.07.030. 